\title{
TEACHING MATHEMATICS IN ENGLISH FOR ELEMENTARY STUDENTS OF ASAK PAROKI MKK
}

\author{
Clara Herlina Karjo \\ English Department, Bina Nusantara University, West Jakarta, Indonesia \\ claraherlina@yahoo.com
}

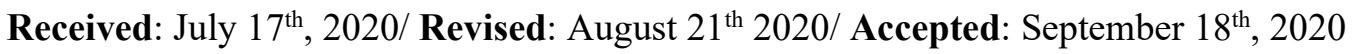

\begin{abstract}
Mathematics subject is considered difficult for most elementary students, especially when the subject is given in English. To be able to do math exercises in English, the students have to understand the math vocabulary and the concepts of math. The purpose of this community development program is to increase the elementary students' ability in solving word math problems in English. The participants in this program are twenty elementary students who are included in ASAK Paroki MKK community. The program is created in the form of classroom teaching and activities. In this program, we teach them the basic concepts of math vocabulary, understanding the word problems and the solutions to the problems. We also use several related activities to make the lessons meaningful and comprehensible. The results show that the students are able to solve math problems in English correctly and confidently.
\end{abstract}

Keywords: Mathematics, English, word problems, math vocabulary, elementary students

\section{INTRODUCTION}

For most elementary students in Jakarta, mathematics is the most dreaded lesson. Doing mathematical exercises can be a tedious work for them, and they tend to avoid doing the exercises altogether. That is why many students get bad scores in mathematics. This problem is also happening for the elementary students who are included in ASAK Paroki MKK community.

To help the students in increasing their math as well as English scores in their school, we were arranging a teaching program of solving math word problems in English. In this program we taught the students the basic math vocabulary in English, understanding word problems, and finding the solution to the math problems. The purpose is twofold, improving their English as well mathematics knowledge.

There are two kinds of mathematical exercise, the one using mathematical notation and the other is called word problem, i.e. "a mathematical exercise where significant background information on the problem is presented as text" (Verschaffel, Greer \& De Corte, 2000). In Indonesian, word problem is known as soal cerita. Because word problems often involve some kind of narrative, they are also called story problems and their use of language will also vary (Moyer, Moyer, Sowder \& Sowder, 1984).

Story problems are often difficult to decipher because it often involves the critical problem solving ability. The ability to solve words problem is crucial for elementary student in mathematics learning (Heddens \& Speer, 2001). This ability can become an important foundation for the children to develop their critical thinking and problem solving skill in the future. Unfortunately, story problems are often 
avoided by the teachers as well as the students. In Wong's (2012) study, it is found that students prefer Multiple Choice questions rather than story problems in mathematics exercises.

To understand word problems, Kaprinaputri (2016) suggests the following steps:

1. Understand the problem. This involves reading carefully the 'story' and tries to understand the problem contained in the story.

2. Change the form. Once the story is understood, try to change the words into mathematical notation. For example the sentence "Annie has two candies and her mother gives her three more candies' can be changed into $2+3$.

3. Do more exercises. Practice doing similar exercises to improve understanding.

Solving word problems in English for Indonesian students can be more complicated, because they need to understand the vocabulary first before being able to understand the problem contained in the story. Therefore, a list of steps highlighted by Robertson (2009) is very helpful in teaching word problems for Indonesian students.

The first step is demonstrating that there might be several meanings in math vocabulary. For example, the common English words such as 'table' have different meaning in mathematics. Most students know that 'table' is meja, but in math, it is tabel. So, pointing out the different meanings of certain vocabulary is important stage in understanding the story problem.

The next step is encouraging students to support one another. It will be easier for the students to understand the material if one student explains the problem to another student in their first language. So students who have understood the problem can explain it to other students who have not understood. Provide

The third step is arranging visual aids, graphic charts, showing gestures, real objects and pictures. Teachers can provides these items to help students understand and master the vocabulary.

Finally, teacher can pre teach the key phrases of the new vocabulary. For example, the words "more than" are similar to "add".

Thus, by implementing the above steps, we devise the program to help the elementary students to learn math in English.

\section{METHODS}

The participants of this program are 20 elementary students from ASAK Paroki MKK. ASAK (Ayo Sekolah Ayo Kuliah) is a non-profit organization managed by Paroki MKK to help the children of low-income families to get proper education. The community development program was given by English Department, Binus University in the form of extracurricular lesson (bimbingan belajar) every Saturday. This particular session on 'Math in English' was delivered on Saturday, December 7, 2019, from 10.00 to 12.00 AM. The location for this program is Gedung PSE, Gereja Maria Kusuma Karmel, Jalan Kusuma no 1, Jakarta Barat. The program was funded by ComDev Binus University with the amount of Rp. 1.350.000,-. The materials for this tutorial program were 10 word problems taken from https://www.prodigygame.com/blog/math-word-problems/

\section{RESULTS and DISCUSSION}

This program is divided into two sessions. The first one is lecturing and class discussion and the second one is playing games based on the problems. 
In the first session, the instructors were giving ten words problems to the students and explain the vocabulary of each problem to the students. Then, the instructor asked the students to discuss the problems with their friends and try to solve the problems together by changing the story into mathematical notation.

The first problem is about addition (penambahan). Here is the problem:

\section{Ashley bought a big bag of candy. The bag had 102 blue candies, 100 red}

\section{candies and 94 green candies. How many candies were there in total?}

The vocabulary in this problem is not too difficult. The students have already known the word 'candy' means permen in Indonesian. They also know the names of color such as blue, red and green. So, this problem can be easily solved. They can change the problems into notation by adding the numbers : $102+100+94$. The result is 296 .

The second problem is about subtraction (pengurangan). The problem is Adrianna has 100 pieces of gum to share with her friends. When she wen. to the park, she shared 10 pieces of strawberry gum. When she left the park, Adrianna shared another 10 pieces of bubble gum. How many piece: of gum does Adrianna have now?

For this problem, the word 'share' has to be introduced and explained as it means memberikan. This word has double meanings because commonly 'share' means membagi which can be misinterpreted as 'to divide' in math, which the notation is (:) instead of 'to subtract' (-). Thus after being discussed, students understand that 'share' means giving, and then they can solve the problem. The notation for this problem is $100-10-10$ and the result is 80 . The other vocabulary discussed is 'gum' which means permen karet. The students immediately understood the word because they knew the item well.

The third problem is multiplication (perkalian), which is given in this story:

\section{A movie theatre has 25 rows of seats with 20 seats in each row. How} many seats are there in total?

To understand this problem, the instructor has to introduce the phrase 'a movie theater'. Yet, since some of the students might not be familiar with a movie theater, it can be compared to a classroom which can be easily understood by the students. So, in a classroom, there are also rows of seat, or barisan bangku. By associating with their classroom, students can analyze that the problem is about multiplication. So they can make the notation of $25 \times 20$ and get the results of 500 seats.

The fourth problem is division (pembagian), which is stated in the following problem:

If you have 80 tickets for the fair and each ride costs 5 tickets, how many rides can you go on? 
For this problem, we have to explain the word 'fair' which means taman bermain. Some students understood this word because they have been familiar with Jakarta Fair, a place where there are a lot of games and rides. However, the word 'ride' has double meanings. In common English, it means 'sit and control on a transport' (mengendarai) as in 'ride a bicycle', but in this case it refers to ' a roller coaster, merry-go-round, or other amusement ridden at a fair'. In Indonesian, 'a ride' can be translated as wahana, but the students are not familiar with this word either. They are more familiar with mainan or komedi putar (merry-go-round). Thus, after all the vocabularies have been understood, they can finally decipher the meaning of this problem. To solve it, they just have to divide $80: 5$ and get the result of 16 rides.

The fifth problem deals with time. The problem is If you wake up at 7:00 a.m. and it takes you 1 hour and 30 minutes to get ready and walk to school, at what time will you get to school? The vocabulary in this problem is not difficult. They know the word 'school'. The instructor only has to discuss the word 'wake up'(bangun tidur), 'get ready' (bersiap) and 'get to' (sampai). Once these words are understood, they know that they have to add the time. Thus, the notation will be 7:00 $+1: 30$. The answer for this is $8: 30$.

The sixth problem is quite difficult, it is about comparing ratio. The problem given is

\section{The school's junior band has 10 saxophone players and 20 trumpet}

players. The school's senior band has 18 saxophone players and 29 trumpet players. Which band has the higher ratio of trumpet to saxophone players?

Ratio means perbandingan. Some students might not have been familiar with this problem. So, first the instructor has to explain what a ratio is. A ratio is a comparison between two values. To solve this problem, the instructor asked the students to identify the problems, sentence by sentence.

Junior : 10 saxophone : 20 trumpet

Senior : 18 saxophone : 29 trumpet

The question for this problem, however, is misleading. It asked which band had the higher ratio of trumpet to saxophone players. It is not asking about the ratio of saxophone against the trumpet according to the order given in the problem, but the trumpet against the saxophone. So, students must be extra careful when reading the question. After discussing this matter to the students, they can give the answer that the junior band's ratio of trumpet players is higher than saxophone players. By notation, this problem can be solved as the following. Note: the order of the numbers should be changed first.

Junior Senior

Trumpet/sax trumpet/sax

$20 / 10 \quad 29 / 18$

2

1.6

Thus, from the notation, we can see that in junior band the ratio of trumpet players is higher compared to that of the saxophone player .

The seventh problem is about Percentages, as stated in the following problem. 


\section{Mary surveyed students in her school to find out what their favorite sports} were. Out of 1,200 students, 455 said hockey was their favorite sport. What percentage of students said hockey was their favorite sport?

The vocabulary for this problem is 'survey', favorite, hockey and percentage. The word hockey is problematic because it is not a popular sport in Indonesia, so students cannot imagine what kind of sport it is. This word is then changed to 'soccer' sepak bola which is more familiar with the students. After that, the concept of percentage is also explained. Thus, once the concepts were understood, they will be able to find the solution to the problem. The notation for this is:

$455 / 1200 \times 100 \%$, and the result is $37.9 \%$.

The eighth problem is calculating averages, which is given in the following problem

For 4 weeks, William volunteered as a helper for swimming classes. The first week, he volunteered for 8 hours. He volunteered for 12 hours in the second week, and another 12 hours in the third week. The fourth week, he volunteered for 9 hours. For how many hours did he volunteer per week, on average?

The vocabularies discussed in this problem are 'volunteer' and 'average'. Volunteer means kerja suka rela. Students were quite familiar with this word and they can understand it quickly. Then, the instructor discussed the word 'average' and told them how to count average. To solve this problem, it has to be broken down into several lines

First week 8 hours

Second week 12 hours

Third week 12 hours

Fourth week 9 hours

The number of hours should be added first into: $8+12+12+9=41$ hours. The result then is divided by four weeks to get the average of volunteering hours per week. The average is $41: 4=10.25$. So, William volunteered an average of 10.25 hours per week as swimming assistant.

The ninth problem is about perimeter or keliling, which is given in the following problem:

\section{The theatre has 4 chairs in a row. There are 5 rows. Using rows as your unit of measurement, what is the perimeter?}

The vocabulary that should be explained in this problem is the word 'perimeter' itself and how to calculate perimeter. The perimeter of a rectangle can be formulated as $\mathrm{P}=2 \times(\mathrm{w}+1) ; \mathrm{w}=$ width, $1=$ length. So using the chairs as height and rows as width, the problem can be translated into the following notation: 
$\mathrm{P}=2(4+5)$, thus the answer is 18.

The last problem is about Area or luas, as in the following

\section{The theatre has 4 chairs in a row. There are 5 rows. How many chairs are there in total?}

Since all the vocabularies have been discussed and they were similar to the previous problem, the instructor only discuss how to calculate 'area' of a rectangle, that is using the formula $\mathrm{A}=\mathrm{w} \mathrm{x} 1$; in which $\mathrm{w}=$ width, $\mathrm{h}=$ length. Thus using the formula, the solution for this word problem is $\mathrm{A}=4 \mathrm{x} 5$, so the result is 20 .

After discussing all the word problems, there are several activities given to implement what the students have learnt. The activities involve using the items in the classroom as the realia.

The first activity is to count the rows and chairs in the classroom. This is done to practice multiplication, perimeter and area. Each student has to count the number of chairs in one row and then calculate the number of rows. They have to draw the map of the classroom based on their calculation. Their drawing will look like this.

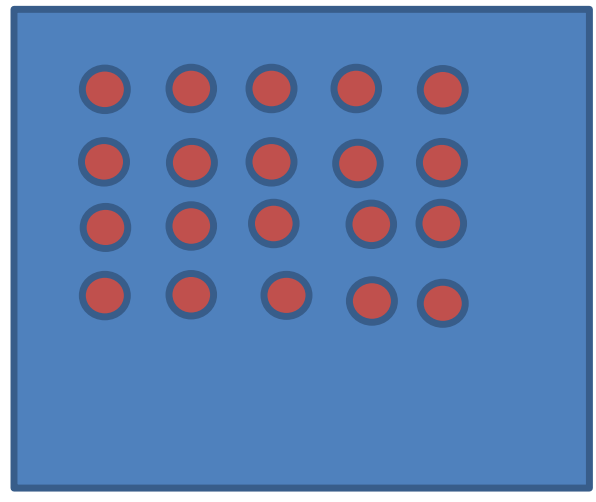

From the picture, they can easily multiply the number of chairs in one row with the number of rows.

The second activity is measuring the height and noting down the age of each student. The students are divided into four groups of five persons. Each group should calculate the average height and ages. Besides practicing calculating the average, this activity is also used to determine the ratio. They will note down the results in the table such as the following.

Table 1 Age and Height

\begin{tabular}{|l|l|l|}
\hline Name & Age & Height \\
\hline Ina & 8 & 120 \\
\hline Agatha & 9 & 140 \\
\hline Seltris & 11 & 145 \\
\hline Krista & 8 & 130 \\
\hline
\end{tabular}




\begin{tabular}{|l|l|l|}
\hline Sherly & 7 & 135 \\
\hline
\end{tabular}

Finally, before finishing the session, the instructor gave them a bag of candy. But, they have to do the division calculation so that everyone has the same amount of candy.

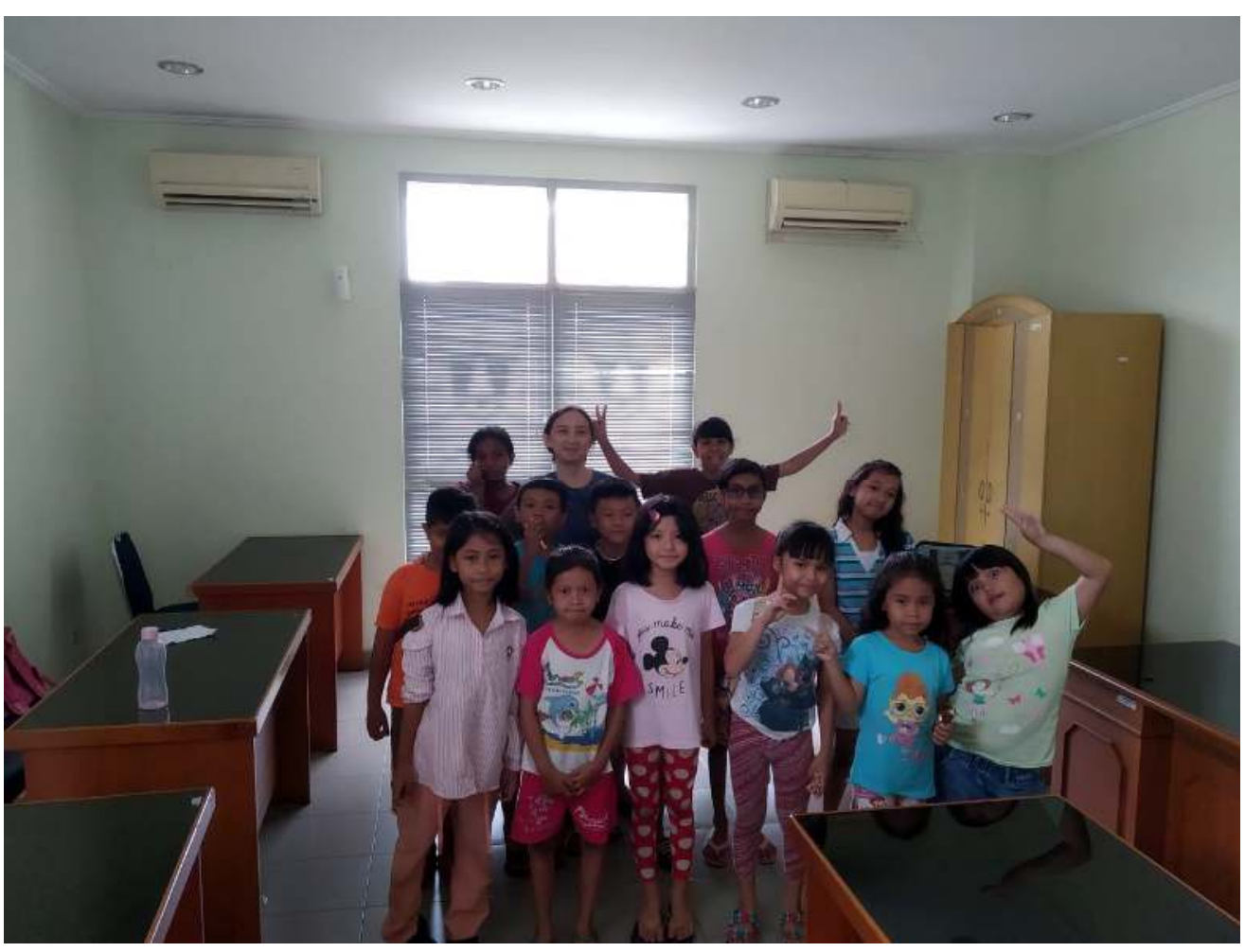

Picture 1. Participants of Math in English 


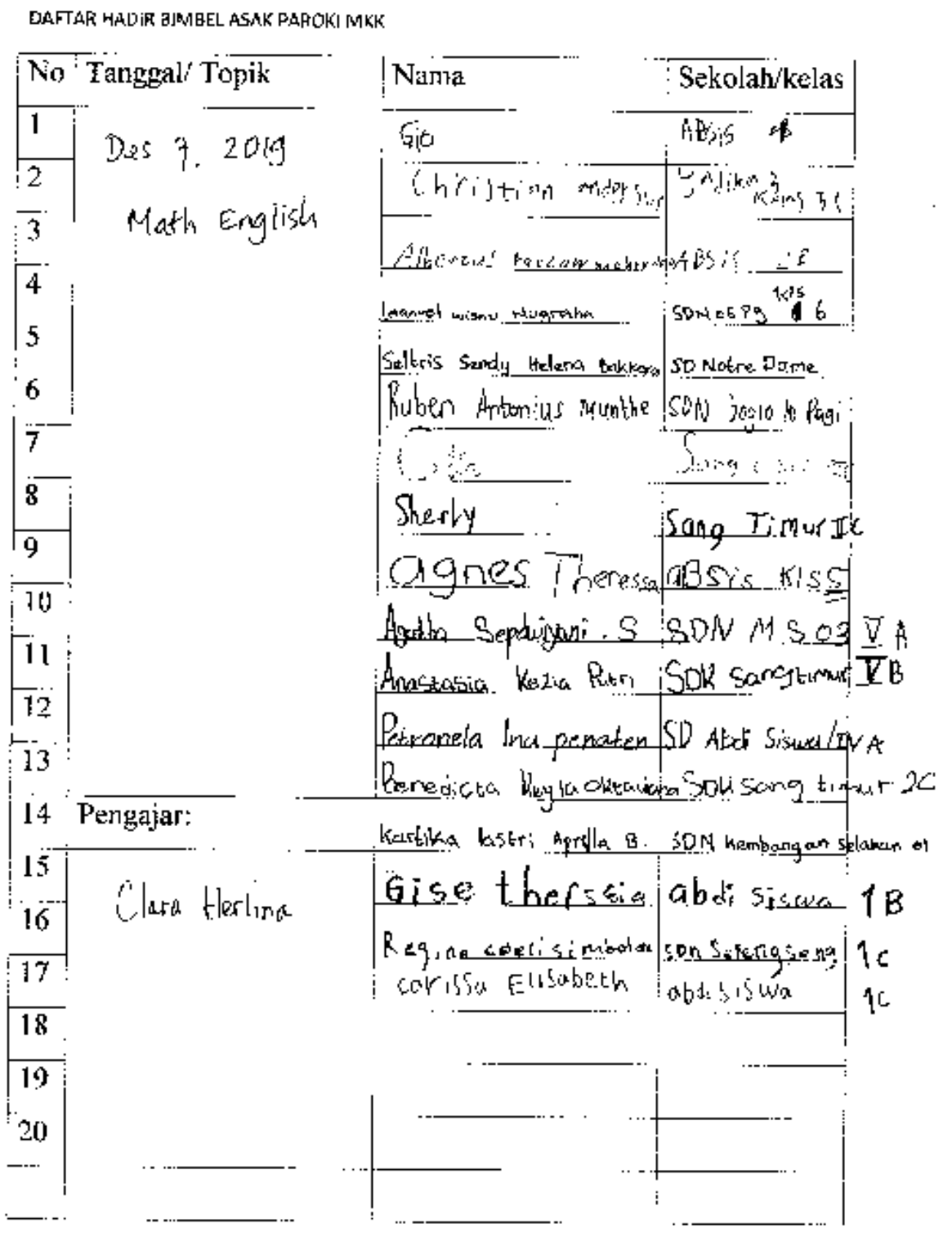

Picture 2. List of attendance 


\section{CONCLUSION}

This community development program has given positive impacts towards the elementary students of ASAK Paroki MKK. They showed their enthusiasm in learning mathematics and English. The teaching and the activities during the program have helped them to enjoy learning mathematics and English. The most important thing is that mathematics can be given in interesting ways. As for the teachers, the best ways to teach mathematics in English for Indonesian students were by pre teach the math vocabulary or the key concepts first, then explain the word problems, sentence by sentence so that the students fully understand the word problem. If they have understood the story, solving the problems will become easier. This kind of program should not be given only once. So, this program is expected to continue in the future because the students need continuous guidance to be better in both subjects, mathematics and English.

\section{REFERENCES}

Brightman, K. A. (2015). Effective strategies for teaching content vocabulary to English Language Learners (Doctoral dissertation).

Ewing, K. \& Huguelet, B. (2008). The English of Math- It's not just numbers! Chapter 8 retrieved from https://www.tesol.org/docs/books/bk_CP authenticityadults 608

Heddens, J.W. \& Speer, W.R. (2001). Today’s Mathematics. New York: John Wiley \& Sons.

Karinaputri, A.P. (2016). Kemampuan menyelesaikan soal cerita matematika. PG PAUD FIP Universitas Negeri Jakarta retrieved from https://media.neliti.com/media/publications/260126-kemampuanmenyelesaikan-soal-cerita-mate-2d268634.pdf

Moyer, J.C., Moyer, M.B., Sowder, L. \& Threadgill-Sowder, J. (1984) Story Problem Formats: Verbal versus Telegraphic Journal for Research in Mathematics Education, Vol. 15, No. 1. (Jan., 1984), pp. 64-68. Retrieved from JSTOR $\underline{748989}$

Robertson, K. (2009). Math Instruction for English Language Learners. Retrieved from https://www.colorincolorado.org/article/math-instruction-english-language-learners

Verschaffel,L., Greer,B., \& De Corte, E. (2000) Making Sense of Word Problems. London: Taylor \& Francis

Wong, Q. C. W. (2012). Testing Mathematics? or Testing English? The Education Quality Accountability Office (EQAO) Grade 9 Mathematics Assessment for English Language Learners (Doctoral dissertation).

120 awesome words problems to engage stiudents 2017 Marcus Guido https://www.prodigygame.com/blog/math-word-problems/ 
